\title{
Influência de uma abordagem histórica dos artigos de Gay Lussac e Avogadro para a formação inicial de professores de Química
}

\section{Adriana Bispo dos Santos Kisfaludy (UFMS) \\ Wellington Pereira de Queirós (UFMS) \\ RESUMO-PÔSTER}

Relacionar e utilizar a história da ciência no ensino é uma dificuldade para docentes da escola básica, pois de acordo com literatura, isso acontece, entre outros problemas, devido a aproximação da história da ciência não ser efetiva na formação de professores e na educação básica. Quando ocorre é de forma reduzida e simplista, como alguns autores apontam: os conteúdos científicos sem contextualização histórica, disseminação de uma ciência puramente empirista-indutivista. Além disso, há uma carência de recursos didáticos fundamentados na História e Filosofia da Ciência que dê condições para o entendimento dos conceitos científicos e de como a ciência foi construída ao longo da história da humanidade. Diante de tais constatações é que abordaremos no presente estudo o processo histórico de construção da teoria dos gases e sua relação com a constante de Avogadro. Para tanto, na realização dessa pesquisa são utilizados artigos originais dos cientistas Gay Lussac e Amadeo Avogadro, encontrados no livro "Molécules Atomes et Notations Chimiques" de 1913. A partir desse estudo histórico a pesquisa visa na perspectiva do modelo formativo reflexivo produzir uma sequência didática com textos históricos para subsidiar a formação inicial de professores de química. 